\title{
Implications of concomitance in technical education financed by Pronatec in the Mato Grosso do Sul State education network (2012-2015)
}

\author{
Arão Davi Oliveira ${ }^{a}$ \\ Valdivina Alves Ferreirab \\ Celeida Maria Costa de Souza e Silva ${ }^{c}$
}

\section{Abstract}

The National Program for Access to Technical Education and Employment (Pronatec) is a program for financing technical education launched in 2011 under the government of Dilma Rousseff (2011-2016) enacted by Law 12.513/2011. Among its actions is the promotion of the Technical Education Networks in the states. This research study discusses the implications of concomitance in the technical education courses financed by Pronatec in the Mato Grosso do Sul State Education Network (REE / MS), in the period from 2012 to 2015. It is a documentary, bibliographical and empirical research study that uses Gramsci's concept of "State" (1991) and Harvey's of "flexible capital accumulation" (1992). Semi-structured interviews were conducted with four managers who participated at the implementation of Pronatec in the REE/MS, during the period studied. The results indicate that in the REE/MS the Pronatec prioritized courses concomitant with or subsequent to standard higher secondary education courses and that resulted in high dropout and failure rates in the studied period.

Keywords: Technical Education; Pronatec; Concomitance.

\section{Introduction}

The Brazilian National Program for Access to Technical Education and Employment (Programa Nacional de Acesso ao Ensino Técnico e Emprego - Pronatec) was launched in 2011 during the government of Dilma Rousseff (2011-2016) and enacted by Law 12.513/2011 "to expand the technical education offer by means

\footnotetext{
a Universidade Católica Dom Bosco, Campo Grande, MS, Brasil

b Universidade Católica de Brasília, Brasília, DF, Brasil

c Universidade Católica Dom Bosco, Campo Grande, MS, Brasil
} 
of technical and financial assistance projects, programs and actions" (BRASIL, 2011). Some of the Pronatec subprograms were implemented under the government of Luiz Inácio Lula da Silva (2003-2010) as actions to achieve the goals of the Education Development Plan (PDE), established by Decree No. 6,094 of April 24, 2007: strengthening and expansion of the Federal Network of Technical Education initiated in 2003; the creation of the E-TEC Brazil Network in 2007; the Brasil Profissionalizado program started in 2007; and finally, the gratuity agreement with the Sistema $S$ implemented in 2008. Pronatec's innovation was to add to these actions two programs: Bolsa-Formação and Fies Técnico.

Pronatec implementation in the education network of the State of Mato Grosso do Sul was conducted according to the criteria established by the Department of Technical Education (SETEC) of the Brazilian Ministry of Education (MEC). Among the eligibility requirements was that involved schools should have a suitable structure for offering technical courses and that the courses should have been functioning for at least one year.

The Ministry of Education endeavor was designed to expand the Technical Education offer throughout Brazil and exploit various possibilities for multiplying enrollments in technical education in accordance with Goal 11 of the Brazilian National Education Plan (214-224) which foresees "tripling the number of enrollments in technical education at the higher secondary education level, ensuring enhancement of the offer through an expansion of 50\% in the public segment (BRASIL, 2014, p. 71). Nevertheless, a study of the results obtained from Pronatec financing in the Education Network of Mato Grosso do Sul State, and of the way in which the offer of the technical courses has been made and their articulation with the regular higher secondary education course, has demonstrated us the issues, including high dropout rates and high failure rates for the period 2012-2015 and their association to concomitance of the courses.

Therefore, this study sought to discuss the implications of concomitant administration of the technical education courses financed by the Pronatec in the Mato Grosso do Sul Education network in the period from 2012 to 2015

This qualitative research of bibliographical empirical and documentary approach makes use of Gramsci's (1991) concept of "State" and Harvey's (1992) idea of the "flexible accumulation of capital". It presents results of semi-structured interviews that were conducted with four managers who had participated in the implementation of the Pronatec in the Mato Grosso do Sul education network (REE/MS) in the period from 2011 to 2015. 
Some researchers have already discussed the issue of dropout and / or concomitance in middle-level professional education, such as Figueiredo and Salles (2017) and Godoi (2014). In these studies, the issue of school dropout is a constant concern for professional technical secondary schools.

The article is organized in three sections. In the first one, we describe our methodological course; in the second, we present the results and some analyses; finally, in the third part, we make considerations about the results of the research.

\section{Methodological course}

It is a qualitative research of documentary, bibliographical and empirical approach that was limited to discuss the implications of the concomitance in professional education in courses financed by Pronatec in the State Educational Network of Mato Grosso do Sul (REE / MS), in the period from 2012 to 2015.

In the documentary research we analyzed the following documents: the National Education and Guidelines Law (LDBEN) 9,394/1996; the National Education Plan (PNE) (2014-2024), Law No. 13,005 of June 25, 2014 (BRASIL, 2014); the Law 12,513 / 2011 (BRASIL, 2011), which created Pronatec, which is our main object of analysis; the REE / MS Class Reports for the years 2012, 2013, 2014, 2015 (MS / SED / COPEP) and the Basic Education Censuses for the years 2010, 2011, 2012, 2013, 2014 and 2015 (BRAZIL / INEP).

The bibliographical research was based on works that approach Brazilian educational in authors who discuss the relation of education and work as an ontological category of human existence that criticize the view of education and work as an economic factor.

The empirical research was conducted through semi-structured interviews with the current director of the selected School; with the director of the School selected at the time of implementation of Pronatec; with the Superintendent of Public Educational Policies and with the Head of the Coordination of Professional Education of SED / MS.

From the empirical material systematized and grouped according to the incidence of respondents' answers, we performed the analyses having as parameters the following concepts and authors: Gramsci's "State" and "hegemony" (1987); Harvey's "flexible accumulation" (1992); Marx (1971); Ramos' "integrated teaching" (2008); as well as the understanding of professional education in Frigotto, Ciavatta and Ramos (2005) and Kuenzer (2001; 2011). 


\section{Results and discussions}

In the State Teaching Network of Mato Grosso do Sul (REE / MS), Pronatec was implemented in 2012 in collaboration with the Union and promoted an expansion in the EPT offer. It prioritized the concurrent and subsequent courses to high school which had high dropout rates in the period 2012-2015.

Table 1 presents data from the School Census for the years 2010 to 2015. These data indicate a $116 \%$ increase in the number of students enrolled in Professional and Technological Education (EPT) in the period from 2011 to 2014 and a slight decrease from 2014 to 2015, which accompanied the downward trend in High School.

We can infer from the table that Pronatec financing did indeed contribute to increasing the place offer for TE in that state. However, in this study the focus of interest was on the numbers of students participating in the Pronatec who failed their grades and those who dropped out without completing their courses in the REE/MS and on what relation those figures had to the concomitant form of administering the technical education courses, which will be explained later.

To provide basic information for construing the problems associated to the pass rates, failure rates and dropout rates in technical education for the period 20122015 in the REE/MS the respective figures are set out in Table 2.

Table 1. Enrollment by stage and modality of teaching in the REE/ MS.

\begin{tabular}{lcc}
\hline Year & High School & $\begin{array}{c}\text { Technical Education } \\
\text { (secondary level) }\end{array}$ \\
\hline 2010 & 86,183 & 2,118 \\
2011 & 86,559 & 3,575 \\
2012 & 86,997 & 4,895 \\
2013 & 86,486 & 7,626 \\
2014 & 86,186 & 7,722 \\
2015 & 79,973 & 7,023 \\
\hline
\end{tabular}

Source: INEP/MEC/BASIC EDUCATION CENSUSES, years: 2010, 2011, 2012, 2013, 2014 e 2015. Adapted by the author, 2016. 
Table. 2 Pass rates, failure and dropout in Technical Education for the period 20122015 in the REE/MS.

\begin{tabular}{lcccccc}
\hline Year & Modality & $\begin{array}{c}\text { Finalized } \\
\text { Enrolment }\end{array}$ & Pass\% & Fail\% & Dropout\% & Others\% \\
\hline 2012 & concomitant/subsequent & 6531 & 77.35 & 13.50 & 8.08 & 1.06 \\
& integrated high school & 1171 & 81.30 & 10.67 & 8.03 & 0.00 \\
& Pronatec & 2264 & 67.98 & 25.00 & 6.85 & 0.18 \\
\multirow{2}{*}{2013} & PROEJA $^{1}$ & 54 & 87.04 & 11.11 & 1.85 & 0.00 \\
& concomitant/subsequent & 8094 & 69.38 & 22.28 & 7.10 & 1.24 \\
& integrated high school & 1219 & 85.07 & 12.88 & 1.89 & 0.16 \\
& Pronatec & 9494 & 61.71 & 28.48 & 7.99 & 1.81 \\
& PROEJA & 69 & 40.58 & 11.59 & 47.83 & 0.00 \\
& concomitant/subsequent & 5673 & 72.47 & 25.12 & 1.55 & 0.86 \\
& integrated high school & 1111 & 83.62 & 13.23 & 3.15 & 0.00 \\
& Pronatec & 4923 & 60.90 & 28.46 & 9.30 & 1.34 \\
& PROEJA & 65 & 43.08 & 6.15 & 50.77 & 0.00 \\
& concomitant/subsequent & 9058 & 47.75 & 18.38 & 1.55 & 32.33 \\
& integrated high school & 1013 & 81.54 & 12.34 & 4.05 & 2.07 \\
& Pronatec & 1920 & 53.02 & 28.28 & 5.68 & 13.02 \\
& PROEJA & 52 & 42.31 & 3.85 & 53.85 & 0.00 \\
\hline
\end{tabular}

Source: MS/SED/SUPED/COPEP, 2016. Adapted by the author in $2016^{2}$.

Comparisons of failure and dropout rates were only made between the figures for the Pronatec courses and those that the Mato Grosso do Sul Education Department (SED/MS) offers in the concomitant and subsequent modalities because it was felt that they were sufficiently similar in their models and mode of operation. Based on the same reasoning, the study excluded the Education for Young People and Adults (EJA) courses and those offered in the integrated ${ }^{3}$ modality from the comparison.

It can be seen from Table 2 that, with exception of the year 2012, when the Pronatec courses registered a dropout rate lower than the SED/MS's concomitant and subsequent courses, in all the other years $(2013,2014$ and 2015) Pronatec

\footnotetext{
Simultaneous adult higher secondary and technical education.

2 Data were made available by the Coordinating Body for Technical Education Policies of the Education Department of the Mato Grosso do Sul State government (COPEP).

3 When the technical course is integrated to the regular general education course the student only enrolls once, in one school. Unlike the case of concomitant or subsequent technical courses where the student has two enrollments, one for the regular course and one for the technical course, and they may be in different schools.
} 
course dropout rates were higher than those for the SED/MS concomitant and subsequent courses. Considering that: 1 ) teachers working with Pronatec classes receive higher salaries than those being paid by the SED/MS; 2) Pronatec students receive an allowance to meet their transport expenses; 3 ) the meals offer is the same for all students whether they are in SED/MS courses or Pronatec courses; then we feel it is important to discuss the elements that could elucidate the link between the fact that Pronatec courses are administered concomitantly and the high dropout and failure rates of students enrolled in courses financed by the Pronatec in the REE/MS.

In mediating the play of forces in which civil society, in the form of corporate interests, prevails, in 2011 the Brazilian federal government created the Pronatec to expand the technical education offer and address the markets' demands for a qualified workforce. Pronatec execution involved collaboration among federal government entities and private institutions in alignment with the terms of Article 3 of Law n ${ }^{\circ} 12.513 / 2011^{4}$.

Kuenzer (2011) sees the kinds of qualification offered in existing Technical Education models as being determined by the unequal and differentiated demands for labor. In other words, "the arrangements are defined by the consumption of whatever labor force is required and not with an eye primarily to qualification as such." (KUENZER 2011, p. 47). The focus now is on the production chain and no longer on the worker's qualification because what will actually reveal whether the worker is qualified or not is his integration to the production chain.

Ramos (2008) considers that the Pronatec achieved progress in terms of expanding technical education's outreach but it has also submitted "social policies to development patterns under the hegemony of financial capital" (RAMOS, 2008, p.12).

Gramsci (1991, p. 33) asserts that hegemony does not translate solely into a question of subordination of the dominated classes to the hegemonic group. Subordinated to the dominant group's hegemony, policies around Pronatec primarily serve capitalist interests, and in the background, observing Gramsci's (1991) theory, they also serve the interests of the subordinated classes: the right to professionalization.

In 2012 the SETEC/MEC only approved 16 technical courses articulated with higher secondary education in the concomitant administration modality which

4 Reading given by Law Lei $n^{\circ} 12.816,2013$. 
were offered in REE/MS with Pronatec financing. In 2013 the number went up to 30 concomitant courses and 8 courses in the subsequent modality ${ }^{5}$. In 2014 some courses were shut down due to a drop in demand for them and also contingencies associated to the federal allocations for Pronatec funding. The number of courses fell to 21 of which 19 were administered concomitantly and 2 in the subsequent modality ${ }^{6}$. No new Pronatec-financed classes were offered in 2015; only those already in course continued, given that the technical courses, which consist of at least 800 class hours, were divided into as many as four modules. Only those courses that had not completed the administration of all their modules were kept on, as shown by the 'Class Authorizations Report for the year 2015'7.

The situation of the Federal Union in 2015 was marked by budget cuts and various Federal Government programs, including Pronatec, ${ }^{8}$ suffered losses in their budget allocations.

Given that context, any arrangements between Federal and State governments to bring about the continuous creation of new courses and expansion of the enrollment offer now depend on an improvement in the national economic situation. That fact has halted the expansion of the course in the REE/MS as can be seen from the statistics in the report of the Mato Grosso do Sul Education Department "Relatório de Autorização de Turma" (Course Authorizations Report)".

In the opinion of Ramos (2012, p. 110), the priority given to the concomitant modality is a sign of the advance of capitalist relations of production because it only highlighted the qualification aspects of the industrialist culture (GRAMSCI, 1991) which are relatively unattractive in terms of stimulating young people to continue with their course. According to Gramsci (1991), for the school to be attractive it needs to be "active and creative", and having work as its guiding educational principle means "offering a qualification based on the historical and ontological process of the production of human existence" (RAMOS, 2012, p. 120).

\footnotetext{
5 Idem 3.

6 Idem 3.

7 Idem 3.

8 The Brazilian Communication Corporation (A Empresa Brasileira de Comunicação - EBC) announced the cuts in the Pronatec on June 10, 2015, a reduction of around 60\% compared to 2014 when over 2.5 million places were made available. The program is among those that have suffered from the $R \$ 9.423$ billion reduction in the budget allocation for the Ministry of Education (MEC). Available at: http://www.ebc.com. br/educacao/2015/06/pronatec-perde-60-das-vagas-este-ano-com-corte-orcamentario. Consulted on: October 15, 2016.

9 Data were made available by the Coordinating Body for Technical Education Policies of the Education Department of the Mato Grosso do Sul State government (COPEP).
} 
The kind of school and qualification that Pronatec stimulates through its collaborative arrangements is a far cry from Gramsci's idea of an integral qualification that endeavors to contextualize the reality the student lives in with the contents of the formal study subjects of the school curriculum. That is because Pronatec actually stimulates fragmentation and technicism, concomitant studies, a very fast qualification and a curriculum that is not articulated to that of the regular higher secondary education. We can see that those factors have contributed to the increases in dropout rates and failure rates in the TE courses.

However, in an effort to diminish the impact of concomitance on student attendance in the TE course, the staff that came into office in the Education Department (SED/MS) from 2015 on altered the way the amounts designed to cover students' transportation costs were transferred, adopting a direct deposit in students' bank accounts. As mentioned previously, the management of Pronatec financing allocated for teachers and students by SED/MS and CEPEF managers underwent a series of modifications largely in the hopes of avoiding the dropout of students from the concomitant courses.

The dropout rate became the object of analyses on the part of the Ministry of Education's Technical Education Department to determine whether the courses under the a egis of Pronatec in the REE/MS and the CEPEF should continue. In regard to the problem of avoiding high dropout rates, Manager 2 spoke of the cost-benefit ratio especially in the light of the results obtained, which made it possible to consider a given course viable or not. Replying to the question about how the implementation and development of the Pronatec had unfolded in the REE/MS and the CEPEF in the period from 2011 to 2015, manager 2 stated:

It was very good; we effectively pay out the real values that Pronatec makes available. [...] So what we did at the end of the year was to say, look at, the course will only continue if you achieve a minimum pass rate of $50 \%$. Not a pass rate, a course completion rate of $50 \%$ to make the course viable. So we asked them to draw up work plans in an effort to avoid dropouts and abandonment (MANAGER 2, 2016).

Godói (2014), comparing the general education in a public institution concomitantly with a technical education in a private institution, stands out the difficulties that beset the development of an emancipatory, and perhaps more practicable, educational process, diminishing dropout rates and maximizing students' performances, and about these issues asserts that, 
To some extent, concomitance has contributed towards exacerbating the distance separating regular higher secondary education and technical education because the partnership arrangements with collaborating private institutions to offer technical courses has exposed the structural differences between private institutions and the realities of state government-run schools. What could be a solution may turn out to be a problem because the scientific knowledge base needed to develop the technical knowledge is not always guaranteed by the student's institution of origin (GODOI, 2014, p. 121).

Although in Godói's speech (2014) the confrontation between the general formation in a public institution concomitant with the technical formation in private institutions is present, the difficulties of developing an emancipatory formation, and even, more feasible, reducing the possibilities of evasion and maximizing students' school performance, are similar when concomitance occurs in the public network itself. In the case of the REE/MS, there is the example of the CEPEF mentioned below in the statement of Manager 4. It so happens that the TE center in question is the technical school in the REE/MS with the largest number of students enrolled in technical courses and one that does not offer regular higher secondary education, only technical courses, concomitant with or subsequent to regular upper secondary education in other schools.

Commenting on his experience in the last-mentioned school, manager 4 also attributed evasion to the fact that there were students with different levels of learning all together in a single class. A given class might have students engaged in any of the three years of higher secondary education. The manager considered that to be discouraging for some of the young people:

In the regular higher secondary education he would go from first to second to third year but when he went to the CEPEF, there they all were together in the same class working with the same knowledge. I believe some of the dropouts may have resulted from that situation, because of the differences in knowledge and skills separating those students (MANAGER 4, 2016).

Those differences in the educational bases among the students in the technical courses administered concomitantly are typical of a curriculum that has not been integrated to the regular higher secondary curriculum, that is to say, they are typical of the concomitance that Godói (2014) referred to and accordingly we argue in favor of concentrating Pronatec financial resources in integrated courses. 
Frigotto, Ciavatta and Ramos (2005) state that the integration of technical education and higher secondary education is a "historically necessary" social condition in order to achieve an education that is unified and polytechnic. However, the present conjuncture in which TE is treated as if it were merely an input for the profitability of the production sector impedes that from happening.

The integral formation thinking defended by Frigotto, Ciavatta and Ramos (2005) also stems from Gramsci's theory (2010) for the emancipation of man through a unitary school that offers an omnilateral formation. In Gramsci's words,

The advent of unitary school means the beginning of new relations between intellectual work and industrial work not only in school but in all social life. The unitary principle, therefore, will be reflected in all organisms of culture, transforming them and lending them new content (GRAMSCI, 2010, 40).

A single school, which in Gramsci's view (1987: 34) is "of general, humanistic, formative culture, which fairly balances the development of the ability to work by hand (...) and the development of working capacities intellectual".

Returning to Table 2, the results from 2014 to 2015 show a decrease in the avoidance rate. We can infer that the payment of the integral amounts to the Pronatec teachers and the direct deposit of the transport assistance allowance in students' accounts were effective actions in the way that they maximized the retention of students in their courses and consequently brought down the dropout rates.

Comparing the pass rates in the Pronatec courses with those of the SED/MS concomitant and subsequent courses shown in Table 2, we find the following:

The pass rates in the Pronatec courses went down year after year as did those of the SED/MS; albeit the latter showed a slight increase in 2014, then went down again in 2015 to a level of $47.75 \%$;

In the years 2012 to 2014, the pass rates in the Pronatec courses were consistently lower than those in the SED/MS concomitant and subsequent courses;

From 2014 to 2015 there was a $12.93 \%$ drop in the Pronatec courses' pass rates. Based on those figures, we can infer that the rupture in the year 2015 in the way Pronatec funding was administered failed to bring about any improvements in the pass rates of those courses. To some extent, the administrative action motivated 
teachers and students and managed to reduce the dropout rate, which one would have thought might have led to improved pass rates, but that is not what happened.

Apart from the relation we were able to establish between the way of managing Pronatec funding, based on the information gleaned from the interviews with the four managers, they also identified other causes for those events especially for the courses administered concomitantly with the regular higher secondary education course with the two courses usually being in different schools.

Moura (2014, p. 356) points out the disadvantages of administering TE courses concomitantly with standard higher secondary education courses insofar as the technical courses are stimulated by the Pronatec funding but without there being any dialogue established with the standard curricular organization "even though the courses alter the student's academic day as he studies the subjects of general education in one shift and in the other he studies his TE subjects and has to go from one school to another to do so" (MOURA, 2014, p. 357).

As it does not offer standard secondary education, the CEPEF only receives students from other schools to attend the technical courses it offers in the contrary shift to the one they are in which they attend their general education courses, which is why the difficulties that Moura (2014) identified are always present in the CEPEF courses administered concomitantly. The same considerations apply to the other schools in the REE/MS system that offer technical courses to students enrolled in standard secondary education in other schools.

When analyzing that specific course format of concomitant administration, Manager 2 had this to say about dropout rates:

[...] one thing we have noticed in our period of management was that the concomitant course is always the one with the highest dropout rate. There is a double enrolment so the student prefers to opt for the standard course and abandon the other when the going gets too heavy and so dropout rates in the technical courses are high; actually, they are extremely high (MANAGER 2, 2016).

The difficulties the managers narrated apply particularly to the courses taken concomitantly with the standard higher secondary course. The managers showed how the causes related to course dropout are linked to: student maturity and awareness when they begin their technical course ; the problem of concomitant examinations in the two schools the student attends; the mixed nature of the 
students in the technical classes with students at all stages of higher secondary education placed together in the same class; the poor quality of primary and lower secondary education; and, lastly, the preferential choice of higher education on the part of students in the last year of standard higher secondary education who have been approved for undergraduate courses in higher education institutions.

We agree with Figueredo and Salles (2017, p. 361) when they understand that the issue of dropout is a social problem, that results in consequences to dropout youngsters themselves, but goes beyond harming the society as a whole. They advocate that there "must be public interest to fight it, that only can be, firstly, throughout the comprehension efforts of its causes" (2017, p. 361).

Among the causes of dropout in EPT those authors stand out,

students difficulties relating to accompaniment to the knowledge of professional aspect; insufficient interest, by part of some teachers, in the support to students in situation of delay; disappointment of the students about technical course, difficulties to reconcile the schedules of high school with technical course, what occurs in the modality of external concomitance, and financial reasons (FIGUEREDO; SALLES, 2017, p. 364).

The causes of dropout cited by Figueredo and Salles (2017) are similar to those mentioned by Manager 3, when reports the difficulties encountered in implementing the Pronatec courses for students enrolled in years 2 and 3 of standard higher secondary education and who are therefore that much closer to concluding their secondary education:

Various factors influence the dropout phenomenon. For example, a student who is studying in standard higher secondary education and is in the second year but only enrolled in the technical course this year: next year he will be in his last year of standard education and only his second year of the technical course. Or a student in his final year in the other school and who is only in his first year here: he will not want to carry on here if he gets selected for university entrance. He is going to opt for the university course not the technical course (MANAGER 3, 2016).

The problems listed above are all fairly typical of technical courses taken concomitantly with regular secondary education courses. Manager 3 also spoke about how the poor preparation in the subjects of Mathematics and Physics of 
students enrolling in the technical courses could contribute to the dropout rate problem and gave an example:

For example, it sometimes happens with a course such as the electrical technician course... well, it is a course that involves a lot of Math and Physics, a difficult course. So, sometimes the student arrives with the illusion that it is all going to be laboratory stuff, all practical and that is fine, but it also involves a lot of theory and the student loses his motivation. So he ends up abandoning it. And that abandonment happens just as much in the concomitant courses as in the subsequent ones (Manager 3, 2016).

Manager 4 identifies other factors that contribute to abandonment, which he associates to a lack of "maturity" on the part of the students that incapacitates them for a commitment to the technical/standard course concomitance and that lack of proper awareness leads them to fail to attend when faced with moments of accumulated tests and evaluations.

Mostly, I attribute the dropouts to an implantation process that failed to arise awareness. [...] It so happened that the student, at the stage of life he was at, would become enthusiastic at the beginning but gradually he would realize that the performance required from him was very high. He would start to miss classes here in the technical course and therein the regular course. Sometimes he would have examinations to take in the technical course that he was unable to conciliate with his regular secondary education schedule and that made things complicated for him (Manager 4, 2016).

We believe that SED / MS should consider the experiences of its managers, regarding the impact of the concomitance of secondary education with TE in the quality of the training that young people receive through this model, because the student's withdrawal from the technical course entails the closure of the class, the unemployment of the hired teacher, and not achieving the goal of training the young person in a technical area.

The integration of secondary education with TE, carried out with a single enrollment, in the same school, favors the planning of the pedagogical team, especially to avoid an overload of assessments of the regular high school and technical disciplines. In integrated teaching, the curriculum is developed in an integrated way; this allows to "organize the knowledge and develop the teaching/ 
learning processes in such a way that the concepts can be assimilated as a system of relations of a concrete totality, which is intended to be explained or understood" (RAMOS, 2012, p. 117).

Our vision of integral formation of the young man is in agreement with the understanding of Kuenzer (2001, p. 43-44) that such a qualification will provide young people that live from their work with a new synthesis of the general and the particular, of the logical and the historical, of theory and practice and of knowledge, work and culture".

We believe that the particular form of TE offer which could make it feasible for young people to obtain an integral qualification and education would be the integrated modality of higher secondary education, and this is in agreement with Ramos (2008), when suggests that technical education that is integrated to higher secondary education establishes the impossibility of disassociating the general educational qualification from preparation for the world of work and provides the young people with a greater understanding of the society they live in and the possibilities for transforming it through their labors in the ontological aspect of the praxis.

This discussion is important because the model Pronatec stimulated in the REE/MS was the concomitant model which, in Moura's (2014) perception, does not allow for the integral qualification of young people insofar as there is no integration of the technical and the standard curricula and also because it makes it difficult for the student to conciliate the separate school routines in a way that would favor his human and technical development. The same author feels that concomitance fosters discouragement of the student, leading to low pass rates and a high rate of course abandonment.

The professional and technical education concomitant with high school does not approach a unilateral formation, as Gramsci theorizes, which allows to combine general knowledge and to develop work skills. Such training could diminish the historical social division between training for work and training to think, direct or plan.

The materialization of Pronatec in the REE / MS prioritizing concomitant and subsequent courses to secondary education, possibly does not escape from the exercise of the hegemony of a "dominant" class that has a block in power.

We believe that the public policies of professional and technological education should be developed along the lines of an omnilateral training theorized by Gramsci (2010). We co-operate with Frigotto, Ciavatta and Ramos (2005), when they question: 
If professional preparation in high school is an imposition of reality, legally admitting this need is an ethical problem. Nevertheless, if what is pursued is not only to meet this need but to change the conditions in which it is constituted, it is also an ethical and political obligation to ensure that secondary education develops on a unitary basis for all. Therefore, secondary education integrated into technical education, on a unitary basis of general formation, is a necessary condition to make the "crossing" to a new reality (FRIGOTTO; CIAVATTA; RAMOS, 2005, p. 49).

The question of expanding access to technical education is strongly linked to class interests. That does not mean that the dominated class does not have its interests addressed, albeit to a lesser extent. "The State which defends private interests needs to have a public dimension given its obligation to address working class demands to obtain the consensus necessary for its legitimation" (COUTINHO, 2006. p. 185).

Considering that the Pronatec is designed to be developed through the collaboration of the Federal Union with governments of the federated states with voluntary adherence to the program on the part of those with a respective demand, all the legal provisions must be complied with. Given that the program embodies a financing policy of optional adherence, the federated entities are induced to adhere to it as a means of guaranteeing funding for their education networks. In the case of the State of Mato Grosso do Sul, adherence to the Pronatec ensured sufficient funding for two thirds of the places offered in TE by the REE/MS in the period 2012 to 2015 . Managers were induced to adhere to the models envisaged by the policy so as not to be left without funding.

We can definitely state that the Pronatec contributed to some extent to weakening both regular higher secondary education and the technical qualification, especially in the case of courses run concomitantly, insofar as they led to serious dropout problems and low pass rates.

\section{Final Remarks}

In the case of concomitance, the disconnection of the higher standard secondary education and the technical one introduces difficulties in the learning process. In many cases, students need a prior knowledge base before entering on a technical qualification course with its own specific contents. Furthermore, concomitance, when the courses are offered in different institutions, makes pedagogical articulation unfeasible in terms of scheduling test sand examinations, controlling the number 
of evaluations in a single week, and participating in projects and activities in non-school environments in the alternative shift period to the study one, whereby if the student attends one he has to be absent from the other school.

Specifically concerning the Technical Education offer in the REE/MS, Pronatec's weakness is in the fact that it does not have the aspects of an omnilateral qualification of the kind Gramsci theorized about and some Brazilian theoreticians like Frigotto, Ciavatta and Ramos (2005) and Kuenzer (2001) have also argued in favor of.

We consider Pronatec as a policy of induction to professional education typical of capitalist states. This view is derived from a model of state in which the dominant class hegemony becomes present in public policies, because when civil society "elects" its representatives, they become part of the political society from which it comes to dominate the legal and coercive apparatus of the state. This forms the extended state theorized by Gramsci.

As Gramsci himself asserts, the hegemonic class does not completely subordinate the dominated classes, since small interests of the dominated classes are present in the hegemony. That is what we can translate, in the case of Pronatec, as the right to professionalization. However, this does not mask the dualistic bias of the proposal of this federal policy.

Another empirical finding of the Pronatec implementation is the Pronatec course approval indexes, which have never been higher than the SED / MS courses. This is a contradiction, since the teachers are better paid and the students receive a scholarship to pay for their travel to the technical course. We can infer that teacher appreciation was not effective in improving the approval indexes, that is, there is a strong influence of the concomitance in the high failure rates in Pronatec courses.

This contradiction that falls in Pronatec courses is typical of a capitalist state policy from which Gramsci (1991) theorizes against monopoly capitalism. That is, the power bloc, representative of capitalist hegemony, makes the state exercise a coercive and ideological function to the point of including politics to the state bureaucracy, especially in planning. From this, it prioritizes an EFA (Education for All) policy with light, flexible and flexible training, subordinating social policies that should be "state policies" to the standards of the phase of flexible capital accumulation. 


\section{Implicações da concomitância na educação profissional financiada pelo Pronatec: na rede estadual de ensino de Mato Grosso do Sul (2012-2015).}

\section{Resumo}

O Programa Nacional de Acesso ao Ensino Técnico e Emprego (Pronatec) é um programa de financiamento da educação profissional lançado em 2011, no governo Dilma Rousseff (2011-2016), sob a Lei $n^{\circ} 12.513 / 2011$. Dentre suas ações, está o fomento às Redes Estaduais de Educação Profissional e Tecnológica. Esta pesquisa discute as implicações da concomitância na educação profissional dos cursos financiados pelo Pronatec na Rede Estadual de Ensino de Mato Grosso do Sul (REE/MS), no periodo de 2012 a 2015. É uma pesquisa documental, bibliográfica e empírica, que utiliza os conceitos: "Estado" de Gramsci (1991) e "acumulação flexível do capital” de Harvey (1992). Foram realizadas entrevistas semiestruturadas com quatro gestores que participaram da implementação do Pronatec na REE/MS, no período estudado. Os resultados indicam que o Pronatec prioriza na REE/MS cursos concomitantes e subsequentes ao ensino médio, o que resultou em altos índices de evasão e reprovação no periodo estudado.

Palavras-Chave: Educação profissional. Pronatec. Mato Grosso do Sul.

\section{Implicaciones de la concomitancia en la educación profesional financiada por el Pronatec: en la red estadual de enseñanza de Mato Grosso do Sul (2013-2015)}

\section{Resumen}

El Programa Nacional de Acceso a la Enseñanza Técnica y Empleo (Pronatec) es un programa de financiación de la educación profesional lanzado en 2011, en el gobierno Dilma Rousseff (2011-2016), bajo la Ley $n^{\circ}$ 12.513/2011. Entre sus acciones está el fomento a las Redes Estaduales de Educación Profesional y Tecnológica. Esta investigación discute las implicaciones de la concomitancia en la educación profesional de los cursos financiados por el Pronatec en la Red Estadual de Enseñanza Mato Grosso do Sul (REEMS), en el periodo de 2012 a 2015. Es una investigación documental, bibliográfica y empírica, que utiliza los conceptos: "Estado" de Gramsci (1991) y "acumulación flexible del capital" de Harvey (1992). Se realizaron entrevistas semiestructuradas con cuatro gestores que participaron en la implementación del Pronatec en la REE/MS, en el periodo estudiado. Los resultados indican que el Pronatec prioriza en la REE/MS cursos concomitantes y subsecuentes a la escuela secundaria, lo que resultó en altos índices de evasión y reprobación en el periodo estudiado.

Palabras Claves: Educación profesional. Pronatec. Mato Grosso do Sul. 


\section{References}

BRASIL. Decreto No 6.094 de 24 de abril de 2007. Dispõe sobre a implementação do Plano de Metas Compromisso Todos pela Educação, pela União Federal, em regime de colaboração com Municípios, Distrito Federal e Estados, e a participação das famílias e da comunidade, mediante programas e ações de assistência técnica e financeira, visando a mobilização social pela melhoria da qualidade de educação básica. Diário Oficial da União. 25 abr. 20017.

. Lei $\mathrm{N}^{\circ}$ 9.394, de 20 de dezembro de 1996. Estabelece as diretrizes e bases da educaço nacional. Brasília, 1996. Diário Oficial da União. 23 dez. 1996.

. Lei $\mathrm{N}^{\mathrm{0}} 12.513$, de 26 de outubro de 2011. Institui o Programa Nacional de Acesso ao Ensino Técnico e Emprego (PRONATEC). Diário Oficial da União, 27 out. 2011.

. Lei $\mathrm{N}^{\mathrm{o}} 12.816$, de 5 de junho de 2013. Altera as Leis nos 12.513, de 26 de outubro de 2011, para ampliar o rol de beneficiários e ofertantes da Bolsa-Formação Estudante, no âmbito do Programa Nacional de Acesso ao Ensino Técnico e Emprego - PRONATEC; 9.250, de 26 de dezembro de 1995, para estabelecer que as bolsas recebidas pelos servidores das redes públicas de educação profissional, científica e tecnológica, no âmbito do Pronatec, não caracterizam contraprestação de serviços nem vantagem para o doador, para efeito do imposto sobre a renda; 8.212, de 24 de julho de 1991, para alterar as condições de incidência da contribuição previdenciária sobre planos educacionais e bolsas de estudo; e 6.687, de 17 de setembro de 1979, para permitir que a Fundação Joaquim Nabuco ofereça bolsas de estudo e pesquisa; dispõe sobre o apoio da União às redes públicas de educação básica na aquisição de veículos para o transporte escolar; e permite que os entes federados usem o registro de preços para a aquisição de bens e contratação de serviços em ações e projetos educacionais. Diário Oficial da União, 6 jun. 2013.

. Lei $\mathrm{N}^{\mathrm{o}} 13.005$ de 25 de junho de 2014. Aprova o Plano Nacional de Educação PNE e dá outras providências. Diário Oficial da União, 26 jun. 2014.

COUTINHO, C. N. O Estado brasileiro: gênese, crise, alternativas. In: LIMA, J. C. F.; NEVES, L. M. W. Fundamentos da educação escolar do Brasil contemporâneo. Rio de Janeiro: Fiocruz, 2006. p. 73-200. 
FIGUEREDO, N. G. S.; SALLES, D. M. R. Educação profissional e evasão escolar em contexto: motivos e reflexões. Ensaio: Avaliação e Políticas Públicas em Educação, Rio de Janeiro, v. 25, n. 95, p. 356-92, abr./jun. 2017. https://doi.org/10.1590/s0104-40362017002500397

FRIGOTTO, G.; CIAVATTA, M.; RAMOS, M. (Orgs.). Ensino médio integrado: concepções e contradições. São Paulo: Cortez, 2005.

GRAMSCI, A. Os intelectuais e a organização da cultura. Rio de Janeiro: Civilização Brasileira, 1991.

. Cartas do cárcere. 3a ed. Rio de Janeiro: Civilização Brasileira, 1987.

. Cadernos do cárcere. .Rio de Janeiro: Civilização Brasileira, 2010.

Vol. 2: Os intelectuais, o princípio educativo.

GODOI, J. A relação público-privado no ensino médio profissionalizante sob a luz da lei 12.513 de 2011 que institui o PRONATEC. 2014. $137 \mathrm{f}$. Dissertação (Mestrado) - Universidade da Região de Joinville, Joinvile, 2014.

HARVEY, D. A condição pós-moderna. 6a ed. São Paulo: Loyola, 1992.

KUENZER, A. Z. Ensino médio e profissional: as políticas do Estado neoliberal. São Paulo: Cortez, 2001.

. As mudanças no mundo do trabalho e a educação: novos desafios para gestão. In: FERREIRA, N. C. (Org.). Gestão democrática da Educação: atuais tendências, novos desafios. 7a ed. São Paulo: Cortez, 2011. p. 43-72.

MARX, K. O Capital, Rio de Janeiro: Civilização Brasileira, 1971.

MOURA, D. H. Educação básica e profissional no PNE (2014-2024): avanços e contradições. Revista Retratos da Escola, v. 8, n. 15, p. 353-68, jul./dez. 2014. https://doi.org/10.15628/holos.2016.4986

RAMOS, M. N. Concepção do ensino médio integrado. In: SEMINÁRIO PROMOVIDO PELA SECRETARIA DE EDUCAÇÃO DO ESTADO DO PARÁ, 2008, Belem, PA. Disponível em:<http://www.nre.seed.pr.gov.br/wenceslaubraz/ arquivos/File/Currículo_integrado.pdf $>$. Acessado em: 25 maio 2015.

Possibilidades e desafios na organização do currículo integrado. In: RAMOS, M. N. et al. (Org.). Ensino médio integrado: concepção e contradições. São Paulo: Cortez, 2012. p. 106-27. 


\section{Informações dos autores}

Arão Davi Oliveira: Mestre em Educação. Doutorando em Educação do Programa de Pós-Graduação em Educação da Universidade Católica Dom Bosco (PPGE-UCDB). Bolsista de Doutorado da Coordenação de Aperfeiçoamento de Pessoal de Nível Superior (CAPES). Docente dos cursos de licenciatura em Pedagogia da Faculdade Campo Grande (FCG) e do Centro Universitário Anhanguera. Contato: e-mail: adodavi@gmail.com (iD) http://orcid.org/0000-0003-0746-2569

Valdivina Alves Ferreira: Doutora em Educação. Docente do Programa de Pós-graduação Stricto Sensu em Educação - Mestrado e Doutorado da Universidade Católica de Brasília (PPGEE/UCB). Contato: e-mail: valdivina5784@hotmail.com

iD http://orcid.org/0000-0002-2306-7465

Celeida Maria Costa de Souza e Silva: Doutora em Educação. Pós-Doutoranda no Instituto de Educação da Universidade Federal de Mato Grosso (UFMT). Docente do Programa de Pós-Graduação em Educação da Universidade Católica Dom Bosco (PPGE-UCDB). Contato: e-mail: celeidams@uol.com.br

iD http://orcid.org/0000-0001-7074-5137 